\title{
Rechtsgeschichte
}

\section{Wim Decock}

\section{From Law to Paradise: Confessional Catholicism and Legal Scholarship}




\section{Abstract}

This paper is a prolegomenon to further study of the intensified relationship between law and moral theology in early modern times. In a period characterized by a growing anxiety for the salvation of the soul (»Confessional Catholicism«), a vast literature for confessors, which became increasingly juridical in nature, saw the light between roughly 1550 and 1650 . By focussing on some of the most important Jesuit canonists and moral theologians, this article first seeks to explain why jurisprudence became regarded as an indispensable tool to solve moral problems. While Romano-canon law showed its merits as an instrument of precision to come to grips with concrete qualms of conscience, with the passing of time it also became studied for its own sake. The second part of this paper, therefore, illustrates how the legal tradition, particularly with regard to the law of obligations, was reshaped in the treatises of the moral theologians. 
I Awareness thereof was revived in no small measure by H. J. BERMAN, Law and Revolution. The Formation of the Western Legal Tradition, Cambridge Mass. I983. For a critical assessment of this book, see P. LANDAU's review in: University of Chicago Law Review 5I (I984) 937-943.

2 Thus, one of the key conclusions to be drawn from M. Godelier, Au fondement des sociétés humaines. Ce que nous apprend l'anthropologie, Paris: Albin Michel 2007. This analysis runs counter to traditional anthropological research which had a tendency to define societies on the basis of common parental lineage or shared economic structures.

3 Recent literature on the subject includes M.F. RenouX-Zagamé, Du droit de Dieu au droit de l'homme, Paris: PUF 2003; M. Stolleis, Das Auge des Gesetzes. Geschichte einer Metapher, München 2004; G. Agamben, Il regno e la gloria. Per una genealogia teologica dell'economia e del governo (Homo Sacer, II. 2), Vicenza 2007; and M. ScAtTola, Teologia politica, Bologna 2007.

4 For a systematic overview of the lasting influence of canon law on the Western legal tradition, see: Der Einfluss der Kanonistik auf die europäische Rechtskultur, ed. by O. Condorelli, F. Roumy, M. Schmoeckel, Bd. I: Zivilund Zivilprozessrecht, Köln 2009 (other volumes forthcoming).

5 See, for example, A. LefebvreTeillard, F. Demoulin, F. RouMY, De la théologie au droit, in: Grundlagen des Rechts. FS Peter Landau, ed. by R. Helmholz et al., Paderborn 2000, 42I-438; and A. Padovani, Perché chiedi il mio nome? Dio, natura e diritto nel secolo XII, Torino I 997.

6 Cf. M. Schmoeckel, Das Gesetz Gottes als Ausgangspunkt christlicher Ethik? Zu calvinistischen Traditionen des I6. Jh.s im Hinblick auf ihre rechtshistorische Relevanz, in: Ius commune 25 ( 1998 ) 347-366; J. WiTte, Law and Protestantism: The Legal Teachings of the Lutheran Reformation, Cambridge 2002; H. J. BERMAN, Law the Protestant Reformations on

\section{From Law to Paradise: Confessional Catholicism and Legal Scholarship}

I. The religious origins of the Western legal tradition

The major contribution of religion and theology to the development of the Western legal tradition is a well-established fact. ${ }^{\mathbf{I}}$ This is quite unsurprising, given the quintessential role that shared religious representations turn out to play in the creation and delimitation of human societies in general. ${ }^{2}$ In the wake of Carl Schmitt and Ernst H. Kantorowicz, many eminent scholars have highlighted the theological foundations of basic juridical concepts, especially in the domain of political thought and public law. ${ }^{3}$ The fruitful input of theological doctrine into legal scholarship famously reached a peak during the classical period of Church law roughly between the I 2 th and 13 th centuries. ${ }^{4}$ Especially, albeit not exclusively, in the field of private law, theological thinking served as a catalyst in the attempt of both the canon and the civil lawyers to reconcile Roman case law with Christian principles. $^{5}$

Yet this influential symbiosis of law and religion is often thought to have come to an end just as it reached its peak in the period of classical canon law. Afterwards, the only crucial development in the Western legal tradition often perceived to be related to religious views is the advent of humanist jurisprudence and natural law doctrines, which occurred in the 16 th and 17 th centuries. The Protestant reformations, especially Calvinism, are said to have attracted some of the most innovative jurists of the early modern period. ${ }^{6}$ At the same time, this epoch seems to mark the birth of legal scholarship as an autonomous discipline, no matter how close the Lebenswelt of the jurists, Protestants and Catholics alike remained anchored in theological thinking and religious practices. ${ }^{7}$ Independent from any confessional views, law itself could finally vindicate its role as a universally applicable tool to establish order and peace. Amidst the horror of the religious wars, the concept of secular law, with which most jurists living in Western societies today identify, ${ }^{8}$ emerged.

the Western Legal Tradition, Cambridge Mass. 2003.

7 M. Schmoeckel, Die katholische Wissenschaft. Die methodische Säkularisation der Jurisprudenz im I6. Jahrhundert, in: Vera Doctrina. Zur Begriffsgeschichte der Lehre von Augustinus bis Descartes, ed. by P. BütTGen, R. IMBACH, U. J. SCHNEIDER, H. J. Selderhuis, Wiesbaden 2009, I67-I7I.
8 It is precisely this self-image of the lawyer as a secular and non-confessional problem-solver, however, which might explain the reluctance of contemporary jurists to recognize the influence of theology on the development of today's legal systems. See the introductory remarks by G. Dolezalek, The Moral Theologian's Doctrine of Restitution and its Juridification in the Sixteenth and Seventeenth 
The turn towards an autonomous legal discipline must be considered a major event in the course of European legal history. However, our fascination with this turning point should not blind us from an equally astounding event which occurred at about the same time in Catholic territories. In the period that spans roughly from 1500 to 1700 , and in territories that range from the Iberian Peninsula to the Holy Roman Empire and the New World, an unprecedented synthesis of law and moral theology took place. ${ }^{9}$ Not without right, some have denoted this explosion of treatises, in which the ius commune and moral philosophy are closely intertwined, as a "second canon law « ${ }^{\circ}{ }^{\circ}$ Although mainly carried out by theologians, this movement, also known as »the late scholas-

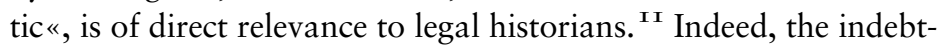
edness of Protestant natural lawyers to theological thinking is beyond doubt. ${ }^{\mathrm{I2}}$ Furthermore, the moral theologians constructed the forum internum as a parallel jurisdiction that competed for normative power with the secular State. ${ }^{{ }^{3}}$

In light of the central role that confession, moral theology and spiritual jurisdiction played in the Catholic Church during the early modern period, it has been proposed that this period be rebaptized as "confessional Catholicism $\ll \cdot{ }^{{ }^{14}}$ This is not to say that a similar preoccupation with the salvation of the soul is not manifest in Protestant traditions. ${ }^{\mathrm{I}}$ Typically, however, the casuistical literature produced by influential Puritans, such as William Perkins (I 558-I602) and William Ames (I576-I633), is far less elaborate than the literature on cases of conscience produced by the great Catholic theologians. ${ }^{16}$ What they share is an obsession with the salvation of the soul and the use of scholastic and casuistical methods to analyse qualms of conscience. The abundant use of the ius commune, however, is a typical feature of Catholic authors. In the Protestant world a clear caesura between theology and law seems to have occurred much earlier than in the Catholic tradition. ${ }^{17}$ Except for some Jansenist strands of thought that would later be condemned as heretic, the Catholics intensified the use of the legal tradition in order to come to grips with moral problems; ${ }^{18}$ in so doing, they in turn transformed the ius commune.

The aim of this paper is to give an introduction to the vast legal literature churned out by moral theologians in the age of "confessional Catholicism «. However, given the endless range of primary

Centuries, in: Acta Juridica. Essays in Honour of Wouter de Vos, ed. by T. W. Bennett et al., Cape Town I992, I04-IO5.

9 K. Seelmann, Theologie und Jurisprudenz an der Schwelle zur Moderne. Die Geburt des neuzeitlichen Naturrechts in der iberischen Spätscholastik, BadenBaden I997; N. BRIESKORN, Skizze des römisch-katholischen Rechtsdenkens im I6. Jahrhun- dert und seine Spuren im Denken der Societas Jesu und des Petrus Canisius, in: Petrus Canisius SJ ( 52 I-I 597). Humanist und Europäer, ed. by R. BERndT, Berlin 2000, 39-75.

Io P. LEgENDRE, L'inscription du droit canon dans la théologie. Remarques sur la Seconde Scolastique, in: Proceedings of the fifth international congress of medieval canon law, Salamanca, 2I-25
September I976, ed. by S. KuTTner, K. Pennington, Città del Vaticano I980, 443-454.

I I It would take too much space here to do justice to the plethora of legal historians who have studied the contribution of the scholastic to legal thought. For ample references to secondary literature on this subject, certainly with regard to the development of contract law, please allow us to refer to the footnotes in W. Decock, Jesuit Freedom of Contract, in: The Legal History Review 77 (2009) 423-458.

I 2 F. Todescan's admonishment needs to be emphasized to the effect that natural lawyers like Pufendorf were much more inspired by the Catholic theologians than they were willing to recognize; see Le radici teologiche del giusnaturalismo laico, III, Il problema della secolarizzazione nel pensiero giuridico di Samuel $\mathrm{Pu}$ fendorf, Milano 200I, 5-6.

I3 As is brilliantly demonstrated in P. Prodi, Una storia della giustizia, dal pluralismo dei fori al moderno dualismo tra coscienza e diritto, Bologna 2000.

I4 On the proposed use of the term "confessional Catholicism «, see J. W. O'Malley, Trent and all that. Renaming Catholicism in the early modern era, Cambridge Mass. 2002, II9-I45.

I 5 Cf. Contexts of Conscience in Early Modern Europe, I 500I700, ed. by H. Braun, E. VALLANCE, Basingstoke 2003.

I 6 For a comparative illustration with regard to the case of duties to inform about external market conditions, see W. Decock, Lessius and the breakdown of the scholastic paradigm, in: Journal of the History of Economic Thought 3 I (2009) 67-69.

I7 From this it should not be derived altogether that the Protestant theological tradition is of less interest to the legal historian than Catholic moral theology of the early modern period, as is obvious from J. Q. Whitman, The origins of reasonable doubt, theological roots of the criminal trial, New Haven, London 2008.

I 8 With regard to the juridification of moral theology in the age of 
confessional Catholicism, see J. Theiner, Die Entwicklung der Moraltheologie zur eigenständigen Disziplin, Regensburg I970, 298-3 IO; M. Turrini, La coscienza e le leggi. Morale e diritto nei testi per la confessione della prima Età moderna, Bologna I99I; R. SCHÜssler, Moral im Zweifel, Paderborn, Bd. I: Die scholastische Theorie des Entscheidens unter moralischer Unsicherheit, 2003 , and Bd. II: Die Herausforderung des Probabilismus, 2006.

I9 An indicative, albeit far from extensive list of relevant authors is contained in C. BERGFELD, Katholische Moraltheologie und Naturrechtslehre, in: Handbuch der Quellen und Literatur der neueren europäischen Privatrechtsgeschichte, ed. by H. CoInG, Bd. II: Neuere Zeit (I 500-I 800). Das Zeitalter des gemeinen Rechts, Teilband I: Wissenschaft, München I977, 999-1033. A good alternative available now is Professor Jacob Schmutz's website: www.scholasticon.fr. It contains a list of scholastic authors which can be searched by affiliation to a certain order.

20 This is a limitation which was succesfully followed in S. KNEBEL's impressive Wille, Würfel und Wahrscheinlichkeit. Das System der moralischen Notwendigkeit in der Jesuitenscholastik, Hamburg 2000.

2I This has already been noted by P. Grossi, La proprietà nel sistema privatistico della Seconda Scolastica, in: La seconda scolastica nella formazione del diritto privato moderno, ed. by P. GrosSI, Milano I973, II7-222; and P. CAPPELLINI, Sulla formazione generale del diritto<, in: Quaderni

sources in this field of study, a further limitation in scope was necessary. Theologians from a variety of different Catholic orders, such as Augustinians, Carmelites, Carthusians, Dominicans, Franciscans, Jesuits, etc., all wrote treatises dealing with legal issues. ${ }^{\text {I9 }}$ This paper's focus is limited to some of the most important Jesuit authors. They have an intellectual tradition so rich on its own that "Jesuit scholastic « has even become an autonomous field of research. ${ }^{20}$ Moreover, from a legal historian's point of view there is a reason to privilege Jesuit literature because it is even more juristic in nature than that of the other moral theologians. ${ }^{2 \mathrm{I}}$ It is not unlikely that the Jesuits have made the most important contribution to the juridical turn witnessed in early modern Catholic moral theology in general. Through the specific example of the Jesuits, this text will explain why Catholic theologians were so avid to borrow from the legal tradition. This point will then be illustrated by providing an overview of some of the major Jesuit legal scholars' works.

\section{Making confession work: the need for law}

The Jesuits' involvement in legal affairs can be considered a direct consequence of their charisma and spirituality. True to their mission of reconciling the active and the contemplative life - an old Christian, and even pagan, ideal - the Society of Jesus ( ${ }^{\circ} \mathrm{I} 540$ ) increasingly engaged in worldly affairs. The Jesuits were driven by a ferocious desire to bring the whole world back to its Creator for the greater glory of God. ${ }^{22}$ This zeal led them to reach out to people of all walks of life from all different kinds of cultures. The Gospel they preached can be summarized as follows: through the sacrament of penance it is possible for man to find consolation and be reconciled with God, surely if he entrusts himself to the guidance of a Jesuit confessor. ${ }^{23}$ The Jesuits believe themselves to be the servants of God par excellence who, on account of their intellectual capacities and practical mastery of the Spiritual Exercises, have the knowledge and prudence to show each man how he must live his life in order to follow God's will. ${ }^{24}$ To make this general claim applicable to concrete cases, however, a more sophisticated and operational device was needed. The Jesuits found these practical tools in the legal tradition.

fiorentini per la storia del pensiero giuridico moderno Io (I98I) 323-354.

22 J. W. O'Malley, The First Jesuits, Cambridge Mass., London I993.

23 Compare M. Maher, Confession and Consolation: the Society of Jesus and its Promotion of the General Confession, in: Penitence in the Age of Reformation, ed. by K. Jackson Lualdi, A. T. Thayer, Aldershot 2000, I 84-200.
24 Accordingly, the first Jesuits were perceived as rivals to secular priests and the religious establishment; the expansion of the order in the Low Countries is a point in case. Cf. E. Put, De stichtingen in de Nederlanden en het Prinsbisdom Luik, in: De Jezuïeten in de Nederlanden en het Prinsbisdom Luik (I 542-I773), ed. by E. PUT, M. Wijnants, Brussel i99I, 2 I. 
As was pointed out in the introduction, the intense relationship between law and pastoral theology reaches much farther back than the Jesuits. During the Middle Ages, all monastic orders, even the most ascetic ones, became deeply involved with law. ${ }^{25}$ They were at once serving as confessors to Christians trying to live a Godpleasing life in the secular world, while simultaneously competing as major economic actors of their times. It is unwise for an historian to divide the flux of historical events into neatly distinguished epochs, or, worse still, to revise the existing caesurae. Were it not unwise, then it would be tempting to reconsider the Middle Ages as a thousand year period beginning with Benedict of Nursia's famous maxim »Ora et labora « as expressed during his Rule around 550, and ending with Luther's symbolic burning of Angelo Carletti de Chivasso's (ca. I4I4-I495) famous manual for confessors, the Summa Angelica (I486) on December, Ioth, I 520 at Wittenberg.

Benedict's Rule had been an authentic exhortation to reconcile the active and the contemplative life. The tradition of manuals for confessors - which enjoyed a boom from at least the fourth Lateran Council ( I 2 I 5 ) onwards ${ }^{26}$ - had eventually tried to determine the practical consequences of that ideal by bringing Roman law and Canon law to bear on cases of conscience stemming from Christians' perceived tension between faith and secular life. Two thirds of the references contained in the Summa Angelica were taken from Roman law, canon law and Medieval jurists. Angelo Carletti de Chivasso himself was a former professor of theology and law at the university of Bologna and a magistrate who eventually became a Franciscan friar. ${ }^{27}$

Martin Luther seems to have succeeded in his damnatio memoriae of I 520 . Until fairly recently little attention has been paid to the fact that the Catholic Church's antagonistic reaction to the Protestant movement actually strengthened the combination of law and theology that had been condemned by Luther. ${ }^{28}$ The Jesuits, well-known supporters of the so-called scounter-reformation', challenged Luther's heterodox view of morality by doing precisely what he had condemned. They gave spiritual advice to the flock by relying on secular philosophy and secular law. Luther thought that only personal faith, divine grace and the Bible could show man how to behave in order to attain spiritual salvation (sola fides, sola gratia, sola scriptura). The Jesuits, on the other hand, remained faithful to the adage of Thomas Aquinas, that grace perfects nature

25 Hence, the fundamental contribution of Franciscans such as Pier Giovanni Olivi (I248-I 298) to contract law and economic thought; cf. S. Piron, Marchands et confesseurs. Le Traité des contrats d'Olivi dans son contexte (Narbonne, fin XIIIe-début XIVe siècle), in: L'Argent au Moyen Age. XXVIIIe Congrès de la SHMESP (Clermont-Ferrand,
I997), Paris: Publications de la Sorbonne I998, 289-308.

26 For example, P. Michaud-QuanTIN, Sommes de casuistique et manuels de confession au moyen âge (XIIe-XVIe siècles), Leuven et al. I962; J. Goering, The Scholastic Turn (I IOO-I 500): Penitential Theology and Law in the Schools, in: A New History of Penance, ed. by A. Firey, Leiden 2008, 2I9-238; J. Goering, The
Internal Forum and the Literature of Penance and Confession, in: The History of Medieval Canon Law in the Classical Period, I I 40I234. From Gratian to the Decretals of Pope Gregory IX, ed. by W. Hartmann, K. Pennington, Washington D. C. 2008, 379-428.

27 For more biographical details, see S. Pezzella, in: Dizionario Biografico degli Italiani 20 (I977) I36-I38.

28 Still there are excellent studies by M. Turrini, La coscienza e le leggi. Morale e diritto nei testi per la confessione delle prima età moderna, Bologna I99I; A. ProSPERI, Tribunali della coscienza. Inquisitori, confessori, missionari, Torino I996; E. Brambilla, Giuristi, teologi e giustizia ecclesiastica dal ' 500 alla fine del ' 700 , in: Avvocati, medici, ingegneri. Alle origini delle professioni moderne (secoli XVI-XIX), ed. by M. L. Betri, A. Pastore, Bologna I997, I69-206; P. Prodi, Una storia della giustizia, dal pluralismo dei fori al moderno dualismo tra coscienza e diritto, Bologna 2000; W. DE Boer, The Conquest of the Soul. Confession, Discipline and Public Order in Counter Reformation Milan, Leiden 200I; R. Rusconi, L'ordine dei peccati. La confessione tra Medioevo ed età moderna, Bologna 2002; V. Lavenia, L'infamia e il perdono. Tributi, pene e confessione nella teologia morale della prima età moderna, Bologna 2004. 
29 Cf. T. Van Houdt, Leonardus Lessius over lening, intrest en woeker. De iustitia et iure, lib. 2, cap. 20: editie, vertaling en commentaar, Brussel 1998.

30 A discussion of the difference between »law « and »morality « as it was conceived of by the moral theologians and the jurists in premodern Europe falls outside the scope of this introductory paper. However, Pothier's short remark in this respect turns out to be illuminating and is worthwhile quoting even with regard to the scholastic notion of "natural obligation «. Cf. R. J. Pothier, Traité des obligations selon les règles, tant du for de la conscience que du for extérieur (édition par M. BERNARDI, Paris I8I3), tom. I, part. 2, chap. 2, p. I32, n. I97: >On ne doit pas confondre les obligations naturelles (...) avec les obligations imparfaites (...). Celles-ci ne donnent aucun droit à personne contre nous, même dans le for de la conscience.<

3I This may sound counter-intuitive to the modern reader. However, another instance of "conscience" as a juristic principle in early modern times is the English Court of Chancery; cf. D. R. KLINCK, Conscience, Equity and the Court

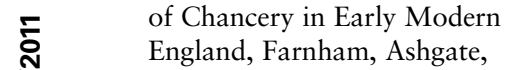

provided that the potential of nature has been developed in the first place (gratia naturam praesupponit et perficit).

Following the medieval manuals for confessors, and again following in the footsteps of the »School of Salamanca ", the Jesuits thought that giving concrete advice to people who wanted to know exactly how to choose the course of action that pleases God in dayto-day life required technical tools necessary to underpin the teachings of the Gospel. Along with other moral theologians, the Jesuits came to recognize that in order to make Christian spirituality operational, it is important to analyse relationships amongst men in a juridical manner. Typically, lawyers analyze social behaviour as consisting of mutual rights and obligations which derive from laws. As a result, Jesuit moral theology emerged from what is generally known as the »law of obligations «. ${ }^{29}$ In this context, it is important to note that the theologians were concerned with determining the rights that person A could invoke against person $\mathrm{B}$ on account of the natural obligation which obligated $\mathrm{B}$ to act in a certain way towards A.

The theologians were not merely concerned with what we now consider to be vague and personal moral principles - e. g. to be grateful to your donor - they were concerned, foremostly, with what jurists such as Robert Joseph Pothier (I699-I772) would call »perfect obligations « (obligations parfaites). Unlike imperfect or moral obligations (obligations imparfaites), perfect obligations, even if based in natural law, could be enforced. As Pothier would also point out, their place of enforcement was not the civil court, but the court of conscience. ${ }^{3 \circ}$ Indeed, the theologians conceived of conscience and a large part of morality in objective and juristic terms. ${ }^{3 \mathrm{I}}$

Contrary to the Protestants, the Catholics, and especially the Jesuits, did not think that the "New Law « (Lex Nova), that is the Gospel, was sufficient to decide what a man needs to do in a particular circumstance in order to please God. Therefore, they explicitly recognized the existence of other sources of law that existed next to the Bible. Jesuits, such as Leonardus Lessius (I $554^{-}$ I623), had a comprehensive and systematic view of the various bodies of law that rule human behaviour. ${ }^{32}$ The main distinction Lessius makes is between natural law and positive law. Natural law (ius naturale) derives from rational nature and the natural condition of things. Contrary to positive law, the rectitude of natural

20I0. Compare W. Decock, La transformation de la culture juridique occidentale dans le premier stribunal mondial , in: F. STEVENS, L. WAELKens (eds.), [Actes du colloque de la Société d'Histoire du Droit, Louvain, 2009 (Iuris scripta historia), Bruxelles, Paleis der Academiën, 20I0 [forthcoming].

32 See L. Lessius, De iustitia et iure ceterisque virtutibus cardinalibus libri quattuor, Antverpiae I62 I, lib. 2, cap. 2, dub. 2, num. 9 , p. 20: $\mathrm{Si}$ [ius] accipiatur secundo modo, pro lege, dividitur sicuti lex. Itaque ius aliud est naturale, aliud positivum; ius positivum aliud est divinum, aliud humanum. Ius divinum aliud est vetus, aliud novum. Ius humanum aliud est ius gentium, aliud ius canonicum, aliud civile. 
law is determined not by a human or divine voluntary disposition, but rather by the inherent nature of things themselves. Hence natural law is immutable - it cannot be altered even by God himself. Men would be subject to natural law even if God did not exist. ${ }^{33}$

Positive law (ius positivum), on the other hand, being true to its etymological sense (< Lat. ponere), derives from a voluntary disposition. As Lessius explains, positive law depends on the free will of God or mankind. Hence, its changeable character even if all circumstances that make up the nature of a case remain unaltered. Positive law subdivides into two main categories depending on whether a positive legal disposition stems from God or mankind, that is: divine law and human law. Divine law (ius divinum) itself is divisible into old divine law and new divine law. Whereas old divine law (ius divinum vetus) coincides with God's legislation in the Old Testament, for example concerning rituals and governance, new divine law (ius divinum novum) encompasses the Gospel and, as Lessius adds in a truly anti-protestant vein, the sacraments. Human positive law (ius humanum) subdivides into three categories. Apart from the laws that are common to all nations (ius gentium), there exists civil law (ius civile) as constituted by secular rulers, and canon law (ius canonicum) as issued by virtue of the authority of the Pope or the Council.

Not only did Jesuits, such as Lessius, draw up cartography of laws, they also found an important connection between objective laws and subjective rights - rights being defined in terms of power based on law (potestas legitima). ${ }^{34}$ Therefore, depending on whether they correspond to natural law or positive law, men dispose of natural rights (ius naturale) or positive rights (ius positivum). Conversely, Lessius and his colleagues also developed the important conceptual notion that a debt or an obligation (debitum) is the other side of a right. ${ }^{35}$ Importantly, the Jesuits arrived at a detailed and scientific analysis of the "system " of law. ${ }^{36}$ Developing these highly influential theoretical observations on laws and rights at the outset of their manuals for confessors, they could then proceed to question which concrete rights and which laws were at play in a particular case of conscience.

So the basic principle is simple: as theologians and confessors, the Jesuits wanted to give advice to Christians of all walks of life, particularly businessmen and princes, so that they would be able to save their souls on the day of Last Judgment. If we look at the

33 On the (late) scholastic origins of the famous "impious hypothesis «, which is usually attributed to $\mathrm{Hu}$ go Grotius, see A. Dufour, Les »Magni Hispani « dans l'œuvre de Grotius, in: Die Ordnung der Praxis. Neue Studien zur Spanischen Spätscholastik, ed. by

F. Grunert, K. Seelmann, Tübingen 200I, $35 \mathrm{I}-380$.

34 Lessius, De iustitia et iure, lib. 2, cap. 2 , dub. 2 , num. IO, p. 20 :
'Si ius accipiatur tertio modo, scilicet pro potestate legitima, dividi potest, primo ex parte principii, nempe secundum divisionem legum quibus oritur. Unde aliud est naturale, quod lege vel concessu naturae competit; aliud positivum, quod lege positiva vel concessione libera Dei vel hominum competit, et sic deinceps in aliis membris.

35 Lessius, De iustitia et iure, lib. 2, cap. 2 , dub. I, num. 7, p. 20: Ex iure enim ipsius in me vel mea, nascitur in me debitum praestandi id, quod illud ius impleat et exhauriat.

36 The same idea has been stressed in the context of demonstrating the profound indebtedness of Hugo Grotius (I $583-1645$ ) to Jesuit moral theological thought, by P. Haggenmacher, Droits subjectifs et système juridique chez Grotius, in: Politique, droit et théologie chez Bodin, Grotius et Hobbes, ed. by L. Foisneau, Paris: Kimé I997, 73-I30; and by P. Negro, Intorno alle fonti scolastiche in Hugo Grotius, in: Divus Thomas 27 (2000) 200-25I. 

that theirs was an age characterised by the explosion of global commercial activity in the wake of the discovery of the Americas. Consequently, there were a number of businessmen who suffered from qualms of conscience about the morality of new business and banking techniques. In the wake of Dominicans, such as Tomas de Mercado, the Jesuits tried to stay abreast of the new and complex challenges that merchants across the globe faced. The theologians of the early modern period felt torn between the actual functioning of markets and the age-old condemnation of interest and speculation. Also in the mayhem of political affairs, the Jesuits tried to find a compromise between political realism (raison d'état) and the Christian dream of a non-Machiavellian way of doing politics. So even if the basic principle of guiding and confessing Christians was simple, confessional practice required much empathy, careful analysis and mastery of legal techniques intended to overcome the complexity of life.

In order to counsel and console Christians living secular lives, a Jesuit must, firstly, be an excellent lawyer. He must have knowledge of the objective bodies of law that determine the subjective rights and obligations that constitute a particular person's legal and moral position. A Jesuit must know the civil law of a concrete city or state, because obligations and rights also follow from these legislative bodies. Suárez's introduction to his highly influential work The Laws and God the Lawmaker (De legibus ac Deo legislatore), published in $\mathrm{I}_{6} \mathrm{I} 2$, is telling in this respect. According to Suárez, theologians have a right and a duty to engage in civil law, since all secular laws derive from God (causa prima). Of course, the direct cause (causa proxima) of a law is the legislator. ${ }^{37}$

Laws derive from God because legislative bodies come into being through a natural process. Thus, for there to be order and peace in a society, authority and power must exist. It is from the "necessity « of power and laws that Suárez derives their »naturalness ", and since nature has been created by God, their indirect »divineness «. All secular societies have been set up by their own members as a means of fulfilling purely human needs. The necessity and naturalness of political order is deduced by Suárez from an imagined "state of nature «.$^{8}$ Suárez is of the view that human beings inevitably form communities given their intrinsically social and linguistic nature. A legitimate form of political power comes

37 Francisco SuÁrez, De legibus ac Deo legislatore, in: Opera Omnia, editio nova a Carolo Berton, Parisiis (apud Vives) I 8 56, tom. 5, Prooemium, p. ix-x; and De defensione fidei catholicae, in: Opera Omnia, editio nova a Carolo Berton, Parisiis (apud Vives) I 859 , tom. 24, lib. 3, cap. 2, num. I, p. 206.

38 The use of the concept of a "state of nature" as a method of consid- ering the basis and necessity of political power first emerges with Suárez and Hobbes; cf. H. HöPFL, Scholasticism in Quentin Skinner's Foundations, in: Rethinking the Foundations of Modern Political Thought, ed. by A. BretT, J. TulLY, H. BLEAKLey, Cambridge 2006, I27-I28. 
into existence for the mere reason that it is necessary for the preservation of the social community. Mankind cannot uphold justice and peace unless it is ruled by an authority which cares for the common good by virtue of its office. Consequently, the legitimacy of political power is made dependent upon its necessity for safeguarding the community, even in the state of nature. ${ }^{39}$ Put differently, positive legislation issued by a prince is binding in conscience because it indirectly derives from God. But, at the same time, these positive laws can only be binding in conscience on the condition that they are not at variance with natural law.

The ambivalent nature of positive legislation that is found in Suárez's political thought is a direct consequence of his intellectual battle against James I. Stuart. The scope of one of Suárez's main political treatises, the Defense of the Catholic Faith (Defensio fidei catholicae), published seven years after the Gunpowder plot (I606), was, indeed, to »deconstruct $^{4 \circ}$ the Protestant claim to the »divine right of kings ", as promoted by James I. Stuart in particular. This political theory directly challenged the divine power of the supreme pontiff and the Roman-Catholic Church. Hence, Suárez points out that the final conclusion to be drawn from his account of the constitutionalist nature of political power is that the power and ambitions of secular princes needs to be restrained. ${ }^{{ }^{\mathrm{I}}}$ Suárez insists that the idea that political power has a contractual basis must be regarded as an eminent "axiom of theology « (egregium Theologiae axioma)..$^{\mathbf{4 2}}$ It would be difficult to find a more concrete example of »political theology«. Suárez stresses that political society is an invention of man himself and not a direct gift from God. In an immediate sense, secular princes derive their power from a contract, not from divine appointment. Subsequent to calculations of self-interest, a public authority is created whose duty is to promote the common good. The legitimate way in which this happens is through the establishment of a "social contract « between the ruler and the citizens.

Lessius, who took classes with Suárez at the Collegio Romano, describes the agreement between citizens and the public authority in terms of an employment contract. ${ }^{43}$ Commenting on the famous Roman »lex regia « (Dig. I, 4, I and Inst. I, 2), Suárez concludes that royal dignity must have been determined by a contract in which the people transferred their power to the prince on the condition and under the obligation that the ruler bears the respon-

39 SuÁrez, De defensione fidei catholicae, lib. 3 , cap. I, num. 3 , p. 203: ' Ratio hujus veritatis, quae ex necessitate hujus principatus et potestatis ejus, et consequenter ex fine illius, qui est conservatio humanae ac civilis reipublicae, sumitur. Homo enim natura sua propensus est ad civilem societatem, eaque ad convenientem hujus vitae conservationem maxime indiget (...) Non potest autem com- munitas hominum sine justitia et pace conservari; neque justitia et pax sine gubernatore, qui potestatem praecipiendi et coercendi habeat, servari possunt; ergo in humana civitate necessarius est princeps politicus, qui illam in officio contineat.`

40 This is the term used in J.-F. CourTINE, Nature et empire de la loi. Études suaréziennes, Paris: Vrin I999, 22.
4 I SuÁrez, De defensione fidei catholicae, lib. 3, cap. 2, num. IO, p. 209: 'Ex quibus tandem concluditur nullum regem vel monarcham habere vel habuisse (secundum ordinariam legem) immediate a Deo vel ex divina institutione politicum principatum, sed mediante humana voluntate et institutione. Hoc est egregium Theologiae axioma, sed vere, quia recte intellectum verissimum est, et ad intelligendos fines et limites civilis potestatis maxime necessarium.<

42 For further discussion, see W. DECock, Counter-Reformation Diplomacy Behind Francisco Suárez's Constitutionalist Theory, in: Ambiente Jurídico I I (2009) 68-92.

43 Lessius, De iustitia et iure, lib. 2, cap. I, dubit. 3, num. I3, p. II. 
44 SuÁrez, De defensione fidei catholicae, lib. 3 , cap. I, num. I2, p. 2 IO.

45 SuÁrez, De legibus ac Deo legislatore, lib. 3, cap. 9, num. 4, p. 202.

46 This is not the place, however, to delve into the well-worn subject of resistance theories in the reformation period. Two recent monographs highlighting the situation in England at the time of Suárez include V. Houliston, Catholic Resistance in Elizabethan England: Robert Persons's Jesuit Polemic, I 580-I6ro, Aldershot 2007 and S. Tutino, Law and Conscience: Catholicism in Early

ᄃ Modern England, I 570-I 625, Aldershot 2007.

sibility for the republic and the administration of justice. ${ }^{44}$ The power of the ruler is limited and qualified by the conditions contained in the contract by which the people conferred their sovereignty upon him. ${ }^{45}$ Moreover, only in an indirect manner can secular power be called divine.

There are at least two practical conclusions to be drawn from this Suarezian political theory: firstly, as a result of its indirect divine nature, a confessor must take positive law into account as a binding source of normativity; and, secondly, a confessor must enforce positive law in the court of conscience only to the extent that positive law is not at variance with natural law and if the public authorities remain within the boundaries of their legitimate power. ${ }^{46}$ To sum up, a good Jesuit theologian needs to master the tools of law in order to implement spirituality in the ministry of confession. In Suárez's words: ${ }^{47}$

The road to salvation passes through free actions and moral rectitude. Since moral rectitude strongly depends on law being, as it were, the rule of human actions, the study of law is a major part of theology. In treating of laws, the sacred doctrine of theology investigates nothing less than God himself in his function as a legislator. [...] It is the task of a theologian to care for the consciences of the pilgrims on earth. Yet the rectitude of consciences is dependent on observing the law just like moral pravity is dependent on breaking the law, since a law is every rule which leads to the gain of eternal salvation if observed as it must be - and which leads to the loss of eternal salvation when it is broken. The study of law, then, pertains to theologians, to the extent that law binds conscience.

3. Every confessor a lawyer:

the need for manuals and legal science

The major awareness amongst early modern Catholic theologians, particularly the Jesuits, that spirituality and morality cannot be made operational unless they are articulated along legal lines, gave rise to a reinforcement of the synthesis of patristic-scholastic philosophy and Romano-canon law that had characterised the Medieval manuals for confessors. From relatively thin manuals of confessors, however, the Jesuit confessional literature increasingly became all-comprehensive, systematic and scientific in nature.

True enough, the first Jesuit manual for the sacrament of confession, the Short Directory for Confessors and Confessants (Breve

47 SuÁrez, De legibus ac Deo legislatore, Prooemium, p. ix-x: Quoniam igitur hujus salutis via in actionibus liberis morumque rectitudine posita est, quae morum rectitudo a lege tanquam ab humanarum acitonum regula plurimum pendet; idcirco legum consideratio in magnam theologiae partem cedit; et dum sacra doctrina de legibus tractat, nihil profecto aliud quam Deum ipsum ut legislatorem intuetur. (...) Deinde theologicum est negotium conscientiis prospicere viatorum; conscientiarum vero rectitudo stat legibus servandis, sicut et pravitas violandis, cum lex quaelibet sit regula, si ut oportet servatur, aeternae salutis assequendae; si violetur, amittendae; ergo et legis inspectio, quatenus est conscientiae vinculum, ad theologum pertinebit. 
directorium ad confessarii ac confitentis munus recte obeundum) published in 1554 by Juan Alfonso de Polanco (I 5 I7-I 576), was still rather vague and prophetic in nature. ${ }^{48}$ But soon the Jesuits would find a more useful guide in the more extensive and technical manual for confessors written by Martin de Azpilcueta (I492I 586), a professor of canon law at Salamanca better known as Dr. Navarrus. His Enchiridion or Manual for Confessors and Confessants (Manuel de confessores y penitentes) (I 552), published in Latin only twenty one years later, was far more adapted to the socio-economic circumstances than was Polanco's Directory. Dr. Navarrus had taken Angelo Carletti da Chivasso's Summa Angelica as a model which thoroughly mixes theology and law, but he took an even more benign stand on many cases of conscience, making his manual particularly appropriate for the confession of the masses.

Not surprisingly, Dr. Navarrus turned out to be very influential on Jesuit casuistry and moral theology. ${ }^{49}$ Francisco de Toledo (I 532-I 596), a former student of Domingo de Soto at Salamanca who was to become a professor at the Collegio Romano, drew inspiration from Dr. Navarrus' Enchiridion or Manual for Confessors and Confessants as he prepared his own Instruction for Priests and Penitants (Instructio sacerdotum ac poenitentium). From its publication in 1596 it was to become an alternative to Polanco's Directory within the Jesuit order, along with Valère Regnault's (I 549-1623) Praxis fori poenitentialis (I6I 6). Interestingly, Regnault expressly modelled his manual for confessors on the structure of Justinian's Institutions: ${ }^{\circ}$

This manual subdivides into three parts according to the three basic elements of jurisprudence in the external courts: persons (personae), actions (actiones), and things (res). The first part concerns the persons in the court of conscience, namely those who participate in the sacrament of penance: the confessor, who is the legitimate judge in this court, and the penitent sinner, who is at the same time the guilty party and the witness, his own defendant and plaintiff, as if he were pleading the cause of God, who is offended by his acts against himself. The second part concerns the actions that are used in the process of confession. For the penitent, those actions involve inner contrition, oral confession and satisfaction through works; for the confessor, performing the sacrament of absolution. The former constitute the material of the sacrament of penitence, the latter its form. Lastly, the third part concerns the things which the practice of confession is about, namely the sins committed by the penitent after his baptism.

48 It was even suggested that its spirit somehow prefigured Jansenist thought; cf. R. A. MARYKs, Saint Cicero and the Jesuits. The Influence of the Liberal Arts on the Adoption of Moral Probabilism, Aldershot, Rome 2008, 70-7I.

49 On the good relationship between Dr. Navarrus and the Society of Jesus, see V. Lavenia, Martín de Azpilcueta (I492-I 586). Un profilo, in: Archivio italiano per la storia della pietà I6 (2003) IO3I I2.

50 V. Regnault, Praxis fori poenitentialis ad directionem confessarii in usu sacri sui muneris. Opus tam poenitentibus quam confessariis utile, Lugduni I 6I 6, pr.: >(...) Institutiones $(. .$.$) digessi tripartitas,$ pro triplice genere attinentium ad iudiciale forum: personarum, inquam, actionum, et rerum, ita ut prima pars complectatur spectan- tia ad personas fori poenitentialis, tanquam eas ex quibus dependet sacramenti poenitentiae usus. Sunt autem confessarius, tanquam iudex legitimus in illo foro; et peccator poenitens, tanquam reus simul et testis, adeoque advocatus accusator sui, tanquam is qui a se offensi Dei causam agat contra semetipsum. Secunda vero pars contineat spectantia ad actiones, in quibus idem usus consistit; quae sunt, quoad poenitentem quidem, contritio cordis, confessio oris et satisfactio operis. Quoad confessarium vero, absolutio sacramentalis. Illaeque sacramenti poenitentiae materiam constituunt et haec formam. Tertia demum pars (...) sit de rebus, circa quas idem usus versatur. Eae autem sunt peccata poenitentis post Baptismum commissa (...). 
5 I Cf. J. Azor, Institutiones morales, in quibus universae quaestiones ad conscientiam recte aut prave fac-

As is obvious from Regnault's far-reaching analogy with the civil courts, in early modern Catholicism conscience was truly thought of in terms of a tribunal. It should not be surprising then that references to Roman and canon law are abundant in Jesuit casuistical treatises and books on moral theology throughout the period. For example, Juan Azor (I536-1603) hastens to add to the title of his famous Moral Institutes (Institutiones morales) that the material of his exposition is based not only on theology, but also on canon law, civil law and history. He pays attention not only to theologians' interpretations, but also to commentaries by canonists, civilians, writers of manuals for confessors and historians. ${ }^{5 \mathrm{I}}$ However, rather than adding names to the extensive list of Jesuit manuals for confessors and casuistic treatises of moral theology, what matters here is to point out, albeit in a merely indicative way, the increasing systematization of the Jesuits' involvement with law. ${ }^{2}$

Of course, Francisco Suárez (I 548-I6I7) from Granada is a famous case in point. In fact, he counts amongst those Jesuits who had not only been trained in philosophy and theology, but foremostly in (canon) law. Although he had almost been refused as a novice when he wanted to enter the Jesuit order in Salamanca, Suárez was to become its most renowned metaphysician. It is worth stressing that he also published several brilliant masterpieces on legal and political theory. The most juridical of his works is the aforementioned treatise on The Laws and God the Legislator (I6I2). It contains some of the most thorough and systematic discussions of the concept of "law « that have ever been written. A short overview of the titles of the ten books of The Laws and God the Legislator will make this abundantly clear: ${ }^{53}$

Book I: On the nature of laws in general, their causes, and their effects Book 2: On eternal law, natural law, and the law of nations

Book 3: On human positive law in itself (as it can be seen in the pure nature of man), also called civil law

Book 4: On canon positive law

Book 5: On the variety of human laws, particularly on criminal laws and laws that are being detested

Book 6: On the interpretation of human laws, their changeability and ending Book 7: On the non-written laws, called custom

Book 8: On favourable human law, viz. on privileges

Book 9: On the old divine positive law

Book ıo: On the new divine law

torum pertinentes breviter tractantur. Omnia sunt vel ex theologica doctrina, vel ex iure canonico vel civili, vel ex probata rerum gestarum narratione desumpta, et confirmata testimoniis vel theologorum, vel iuris canonici aut civilis interpretum, vel summistarum, vel denique historicorum, Lugduni I6I 2 .

52 See R. A. Maryks, Census of the Books Written by Jesuits on Sacra- mental Confession (I 554-I650), in: Annali di Storia moderna e contemporanea IO (2004) 4I5519.

53 Cf. F. SuÁrez, De legibus ac Deo legislatore, in: Opera Omnia, editio nova a Carolo Berton, Parisiis (apud Vives) I 856 , tom. 5, p. v-vii (juncto tom. 6, p. vi-vii). 
Suárez's philosophy of law had a big influence both in Catholic and Protestant countries right from his treatises' inception. Because of his account of the law of nations (ius gentium), he ranks among the mythical founders of international law. ${ }^{54} \mathrm{He}$ is still important to philosophers of law today ${ }^{55}$ and it is also easy to see how many of the ideas Suárez developed are mirrored, albeit in a secularized form, in contemporary standard legal textbooks. For example, Suárez's insistence on the territorial scope of laws, his theory of subjective rights, legal fictions, presumptions, the distinction between void and voidable contracts, the need to promulgate a law in order for it to become binding, and so on, were, and are, wellregarded in legal circles. Indeed, Suárez's The Laws and God the Legislator displays a detailed analysis of many of the basic legal principles that we now take for granted, but which had not been fully developed until the early modern scholastic period. By the same token, Suárez's thorough analysis of the contractual nature of political power and his methodological conception of the state of nature as developed in his Defense of the Catholic Faith (16I3) which was a rebuttal of the theory of the divine right of kings as advocated by the apostate James I. Stuart - prefigures important strands in modern political theory. ${ }^{56}$

Although Suárez is undoubtedly the Jesuit most widely known to have made a fundamental contribution to legal thinking, he is by no means the only one. Perhaps he even borrowed many ideas from his colleagues. This is hardly surprising. Back from a mission to China, François Noel composed a companion to Suárez's theology in which he pointed out that Suárez's mind may have been far too sublime and speculative to be able to dwell on rather vulgar and practical day-to-day affairs. ${ }^{57}$ Consequently, he decided to add a summary of Tomas Sánchez's On Marriage and of Leonardus Lessius' On Justice and Right to the companion. ${ }^{58}$ These additions were praised for being the most frequently studied works in Jesuit colleges on these practical matters worldwide.

The Jesuit and canon lawyer Thomas Sánchez (I 550-I6IO) from Cordoba wrote an influential treatise On Marriage (Disputationes de matrimonio) amongst several other important moraljuridical treatises. ${ }^{59}$ Because of its vastness and detail, Sánchez's On marriage outshines the earlier and rather modest attempt by Jesuit Enrique Henríquez ( I 546-I608) to treat the canon law of marriage. Henríquez dedicated an entire book of his Summa Theo-

54 See, inter alios, J. B. Scott, Victoria et Suarez. Contribution des théologiens au droit international moderne, Paris: Pedone I939; and J.P. Doyle, Francisco Suárez on the Law of Nations, in: Religion and International Law, ed. by M. W. Janis, C. Evans, London I999, I03-I20. For recent bibliography on Suárez in general, see the section dedicated to him on the above mentioned website: www.scholasticon.fr.

55 Cf. P. C. Westerman, Suárez and the formality of law, in: Politische Metaphysik. Die Entstehung moderner Rechtskonzeptionen in der Spanischen Scholastik, ed. by M. Kaufmann, R. Schnepf, Frankfurt am Main et al. 2007, 227-238; J.-F. Schaub, Súarez. Les lois, in: Dictionnaire des grandes œuvres juridiques, ed. by
O. Cayla, J.-L. Halpérin, Paris: Dalloz 2008, 565-570.

56 Among the major recent books on Suárez's political thought, see J.-F. Courtine, Nature et empire de la loi. Études suaréziennes, Paris: Vrin I999.

57 Noël is known for his Sinensis imperii libri classici sex, Pragae I7 I I, a Latin translation of classical Chinese philosophy which formed the basis for Christian Wolff's observations on Chinese culture. See Der Westen in China China im Westen. Bibliography and Biography Database, ed. by East Asian Seminar @ University of Zurich, http://www.ostasien. uzh.ch/sinologie/forschung/ chinaundderwesten_en.html, passim (visited on I0.08.20IO).

58 Cf. F. Nö̈L, Theologiae Francisci Suarez e Societate Jesu summa seu compendium in duas partes divisum, duobusque tractatibus adauctum; primo de justitia et jure, secundo de matrimonio, Coloniae I732, Appendix ad Suarez, I-2. Curiously, the economic historian R. De Roover attributes the short discussion on bills of exchange which is included in this anthology to Suarez, while it is actually part of the supplement On Justice and Right, which is a summary of Lessius's legal and economic thought; cf. R. DE RoOver, L'évolution de la lettre de change ( $14 \mathrm{e}-\mathrm{I} 8 \mathrm{e}$ siècles), Paris: Armand Colin I953, 202.

59 On Sánchez, see J. M. ViejoHiménez, s. v. Sánchez, in: Diccionario crítico de juristas españoles, portugueses y latinoamericanos (hispánicos, brasileños, quebequenses y restantes francófonos), ed. by M. J. Peláez, 2.I, Zaragoza, Barcelona 2006, 480-48I. 
logiae Moralis to marriage law, which was simply cited as his $\mathrm{On}$ Marriage by subsequent authors such as Sánchez. ${ }^{60}$ Sánchez's On Marriage would remain one of the works referenced in postTridentine matrimonial law. At the beginning of the twentieth century, Pietro Gasparri (I 852-I934), the Secretary for the Commission for the Codification of Canon Law, drew heavily on Sánchez as he prepared the new Code of Canon Law (I9I7). ${ }^{61}$

Studying Sánchez requires a certain amount of courage and perseverance, not in the least because his argument is often floating and self-contradictory, even if the general structure of his treatise is systematic and clear. Yet no one runs the risk of being disappointed by Sánchez's stimulating reasoning and prudent counsels in very concrete matters. The expressive terms in which he describes the casuistry surrounding certain impediments to a valid marriage have struck eminent historians of canon law as being almost tantamount to mild forms of pornographic literature. ${ }^{62}$ When it comes to the development of contract law, Sánchez's doctrine of the vices of will - particularly mistake and duress - has been seminal. This is due to the fact that much of Sánchez's detailed analyses with regard to the validity of marital consent were then applied by other Jesuits like Lessius to other contracts. The table of contents from Sánchez's work On Marriage gives a rough idea of his systematic approach to marriage law and its relevance to other domains of contract law: ${ }^{63}$

Book I: On engagement

Book 2: On the essence of marriage and marital consent

Book 3: On clandestine consent

Book 4: On coerced consent

Book 5: On conditional consent

Book 6: On donations between spouses, premarital gifts, and jointures

Book 7: On marital impediments

Book 8: On dispensations

Book 9: On marital obligations

Book ı०: On divorce

For historians of moral theology as well as philosophers of law it is useful to also consider Sánchez's Opus morale in praecepta Decalogi. However, this will not be undertaken here due to limited space and the need to consider the other Jesuit whose work was thought of such importance that it must be added to the anthology of Suarezian thought: Leonardus Lessius (I 554-I623). Ever since

60 In the Venice edition of I600, the canon law of marriage is dealt with autonomously by ENRIQUE HenRíquez in book I I of his Summa theologiae moralis tomus primus.

6i Cf. C. Fantappiè, Chiesa Romana e modernità giuridica, Tom. I: L'edificazione del sistema canonistico (I 563-I903), Milano 2008, 447-458.
62 See J. Brundage, Law, Sex and Christian Society in Medieval Europe, Chicago, London I990, 564-567; M. Madero, Peritaje e impotencia sexual en el De Sancto Matrimonio de Tomás Sánchez, in: Eadem utraque Europa (2008) IO5-I 36 .

63 See T. Sánchez, Disputationes de sancto matrimonio sacramento tomi tres, Antverpiae I620, index. 
the Renaissance of Thomism at the threshold of the 2oth century, this renowned Jesuit from Antwerp has drawn much attention for his masterpiece On Justice and Right and the other Cardinal Virtues (De iustitia et iure ceterisque virtutibus cardinalibus) by historians of moral, economic and legal thought. ${ }^{64}$ Impressed with Roberto Bellarmino's fiery sermons during his studies at the Arts faculty in Louvain, Lessius entered the Society of Jesus in I 572 and soon became a teacher of Aristotelian philosophy at the College d'Anchin in Douai - a job which left him enough spare time to teach himself Roman and canon law.

Upon finishing his theological studies at the Collegio Romano, Lessius became a professor of moral theology at the Jesuit College of Louvain in 1585 . For the exercises in practical ethics and casuistry, which he considered to be the hallmark of the Jesuit order, he made use of the Salamancan canonist Dr. Navarrus' Manual for Confessors. Even if Lessius is best known among theologians for his tenacious defence of molinism in the debate on grace and free will, his moral theological and juridical masterpiece is the treatise On Justice and Right, which enjoyed numerous re-editions across Europe until the I 9 th century. ${ }^{65}$

Lessius' On Justice and Right played a vital role in the history of the law of obligations. In his On the Right of War and Peace (De iure belli ac pacis) the alleged father of modern natural law, Hugo Grotius (I $583-1645$ ), frequently gives an elegant summary of the extensive arguments that were first developed by Lessius and other late scholars. Embarrassingly, this often leads Grotius to copy the same incorrect references as did Lessius. ${ }^{66}$ Also in regard to the history of commercial law, Lessius' work is not insignificant. For instance, in order to get the best analysis of financial techniques used by merchants and bankers at the Antwerp Bourse, the jurist Zypaeus (I580-I650) from the Southern Netherlands recommends lawyers read Lessius' De iustitia et iure. ${ }^{67}$ Given his reputation for sharp economic analyses, it should not even come as a surprise that Lessius became a source of inspiration for Kaspar Klock from Soest (I $583-1655$ ) in the more technical parts of his De aerario, a comparative study of state financing. ${ }^{68}$

In any event, in Lessius' On Justice and Right, the casuistry of the legal and moral tradition is ordered within a systematic whole. As Lessius' elaborate concept of law has already been mentioned, it should suffice here to point out an element in the construction of

64 For details on Lessius's life and times as well as references to secondary literature, see T. VAN Houdt, W. Decock, Leonardus Lessius: traditie en vernieuwing, Antwerpen 2005. Especially worthy of mentioning in this context is T. VAN HoudT, De economische ethiek van de ZuidNederlandse jezuïet Leonardus Lessius (I 554-I623): een geval van jezuïtisme?, in: De zeventiende eeuw I4 (I998) 27-37.

65 T. VAN HoudT, Leonardus Lessius over lening, intrest en woeker, pp. Xviii-Xxv.

66 See R. FeEnstra, L'influence de la Scolastique espagnole sur Grotius en droit privé: quelques expériences dans des questions de fond et de forme, concernant notamment les doctrines de l'erreur et de l'enrichissement sans cause, in:
La seconda scolastica nella formazione del diritto privato moderno, ed. by P. Grossi, Milano I973, 377-402.

67 F. Zypaeus, Notitia iuris belgici, Antverpiae I675, lib. 4, p. 6I.

68 Cf. K. KLock, Tractatus juridicopolitico-polemico-historicus de aerario, sive censu per honesta media absque divexatione populi licite conficiendo, libri duo, mit einer Einleitung herausgegeben von Bertram Schefold, Hildesheim u. a. 2009, passim. 
Lessius' book which is symptomatic of the shift towards systematic legal thinking. Before discussing the particulars of property law, Lessius gives an account of justice in general (de iustitia in genere) and right in general (de iure in genere). By the same token, his comprehensive analysis of illicit acts or torts is preceded by a chapter on injustice and restitution in general (de iniuria et restitutione in genere). Last but not least, his treatment of particular contracts follows his treatment of general contract law (de contractibus in genere). A quick look at the contents of the second book of Lessius' treatise shows us how thoroughly and systematically the law of property, torts and contracts were discussed by Lessius, next to selected topics in procedural law, tax law and canon law: ${ }^{69}$

Section I. On justice, right, and the specific types of right

I. On justice in general

2. On right in general

3. On dominion, usufruct, use and possession, which are specific types of rights

4. On who is capable of having dominion and over what

5. On the mode of acquiring dominion over goods that belong to nobody or over goods which are common to all, particularly on servitudes, hunting, fishing, fowling and treasures

6. On the mode of acquiring dominion over someone else's good, particularly on prescription

Section II. On injustice and damage in all kinds of human goods and their necessary restitution

7. On injustice and restitution (which is an act of justice) in general

8. On injustice against spiritual goods

9. On injustice against the body through homicide or mutilation

Iо. On injustice against the body through adultery and fornication

II. On injustice against reputation and honour through detraction and defamation

I2. On injustice against property through theft, robbery or damage. I3. On cooperating to theft or injury

I4. On restitution by virtue of the good received and the receiver of restitution

I 5. On the respective order and the way in which restitution has to be made, where restitution must be made and what to do with the expenses I6. On the factors which excuse from restitution

Section III. On contracts

I7. On contracts in general

I8. On promise and donation

19. On testaments and legacies

20. On loan for consumption and usury

69 L. Lessius, De iustitia et iure ceterisque virtutibus cardinalibus, lib. 2, p. I3-I4. 
2I. On sale-purchase

22. On rents

23. On money-exchange

24. On lease-hire, emphyteusis and feudal contracts

25. On companies

26. On games and gambling

27. On deposit and loan

28. On suretyship, pawn, mortgage

Section IV. On injustice in judgments and courts

29. On judges

30. On plaintiffs and witnesses

3 I. On lawyers and defendants

Section V. On distributive justice

32. On favouritism in general

33. On levies and taxes

34. On benefices

35. On simony

Section VI. On religion, which is the first part of justice

36. On religion in general

37. On praying and praising God

38. On sacrifices and adoration

39. On tithes

40. On vows

$4 \mathrm{I}$. On the religious state

42. On swearing and oaths

43. On superstition and its forms

44. On magic

45. On irreligiosity

Section VII. On virtues connected to justice

46. On the other virtues connected to justice in which there is legal debt

47. On virtues connected to justice in which there is moral debt

Lessius' is a relatively concise treatise on legal and moral problems written in a crystal-clear and plain style. The six-volume treatise On Justice and Right published over the period I 593-I 600 by his friend and colleague Luís de Molina (I 535-I600), however, was more detailed and voluminous. ${ }^{70}$ It is obvious from a quick glance at the sheer titles of the six volumes constituting Molina's impressive On Justice and Right that this is an extremely rich treatise that not only deals with vast areas of private law, but also of public law: ${ }^{7 \mathbf{I}}$

Volume r: On justice, rights, property law, family law, successions

Volume 2: On contracts

Volume 3/r: On primogeniture and taxes

Volume $3 \%$ : On delicts and quasi-delicts

70 On Molina, see, F. B. Costello S. J., The Political Philosophy of Luis de Molina, Roma I974, and F. Gómez Camacho S. J., Luís de Molina. La teoría del justo precio, Madrid I98I.

7I L. Molina, De iustitia et iure tomi sex, Moguntiae I6I4. 
Volume 4: On commutative justice in corporeal goods and goods belonging to people connected to us

Volume 5: On commutative justice in the goods of honour and reputation, and also in spiritual goods

Volume 6: On judgment and the execution of justice by the public authorities

Molina had been the first Jesuit to adopt the type of moral theological literature known as On Justice and Right - the first work of its kind having been written by the Salamancan Dominican Domingo de Soto in I 553/6. These treatises actually grew out of commentaries on Thomas Aquinas' Secunda Secundae, as can still be seen in the Commentarii theologici of Gregorio de Valentia (I550-1603), a Spanish Jesuit who taught at the University of Ingolstadt. Yet these commentaries soon became increasingly independent from their source. This eventually led to the creation of an autonomous genre of moral theological literature at the university of Salamanca, where an important renewal of theological thought took place in the course of the sixteenth century. ${ }^{{ }^{2}}$

In contrast to Soto's work, the Jesuits' treatises On Justice and Right were far more systematic, voluminous and technical. As has been pointed out before, the Jesuits were much more acquainted with the ius commune and the juridical thinking of their time. Molina's references to contemporary Portuguese and Spanish law or commercial practices are even more abundant than Lessius' useful observations on contemporary law and commercial customs in the Low Countries. Molina's citations of scholastic authorities also outnumber those in Lessius. In this regard, Lessius appears to have integrated the humanist critique on scholastic methodology to a greater extent and he also seems to have cared more about the reader-friendliness of his book. Yet the general scope of both treatises is the same, namely to give a systematic outline of law for the purpose of spiritual guidance. As a result, the Roman and canon legal traditions on the one hand, and Aristotelian-Thomistic moral philosophy, on the other, were united in Lessius' and Molina's On justice and right. This synthesis lived on, albeit in a degenerate form, in the Codes that rule modern jurisdictions. ${ }^{73}$

The third Jesuit who wrote a successful treatise On Justice and Right was Juan de Lugo ( $1583-1660$ ), a canon lawyer by training, who went on to become a professor of theology at the Collegio Romano before being named a Cardinal by Pope Urban VIII in I643, the year after the publication of his Disputations on Justice teología en el siglo XVI, Madrid 2000 .

73 This has been argued by J. GorDLEY in Philosophical Origins of Modern Contract Doctrine, Oxford I99I, and in Foundations of Private Law, Property, Tort, Contract, Unjust enrichment, Oxford 2006. 
and Right (Disputationes de iustitia et iure). ${ }^{74}$ He shared a thorough understanding with Molina and Lessius of different kinds of law and their application to qualms of conscience, but he also had a tremendous insight into the actual functioning of life, particularly with regards to business and economic affairs. ${ }^{75}$ Both in regard to form and content, Lugo seems to be heavily indebted to Lessius, although he is certainly not a servile imitator. Lugo further developed the Jesuits' systematic approach to law and morality but sometimes could not avoid the pitfalls of casuistry.

Although the Jesuits displayed a terrific knowledge of the legal tradition, it is remarkable that only a few among them were actually jurists by training. Besides Francisco Suárez and Juan de Lugo, who had studied law in Salamanca, there is one Austrian Jesuit who stands out for his achievements as a true canon lawyer, namely Paul Laymann (I 574-I 635) from Arzl near Innsbruck. As a professor of moral theology at the Jesuit college of Munich (I609I625) he was the promoter of theses on, for example, the salepurchase contract, or the fundamental difference between ius and factum..$^{76} \mathrm{He}$ also finished his monumental five books on Moral Theology in Munich. These books offer a systematic, methodical and comprehensive overview of moral theology, full of references to Romano-canon law. This is particularly the case in the book On Justice and Right, which is highly reminiscent of Molina and Lessius' discussions on property, delicts and contracts. ${ }^{77}$

Laymann's Moral Theology is another testimony to the fact that it would be particularly temerarious to distinguish too sharply between law and morality in Jesuit moral theological thinking of the early modern period. This symbiosis of law and ethics can also be seen in Jesuit treatises dedicated expressly to "morality «, for example Vincenzo Figliucci's (I 566-I622) Quaestiones morales or Hermann Busenbaum's (I600-I668) Medula theologiae moralis. But to return to Paul Laymann, he not only wrote moral theological treatises that were heavily imbued with legal thought, he also dedicated himself to studying the canon legal tradition itself in a systematic way; after all, he had obtained a chair in canon law at the university of Dillingen and held it from I 625 onwards. In this period he undoubtedly started writing his commentaries on the Decretales of Pope Gregory IX (I 234) and on Pope Boniface's VIII (I 298) Liber sextus, which were published posthumously as Canon law or Commentaries on the Decretals. ${ }^{78}$ The editor explained the

74 For further details, see E. OLIVARES, Juan de Lugo (I $583-$ I660): Datos biográficos, sus escritos, estudios sobre su doctrina y bibliografía, in: Archivo Teológico Granadino 47 (I984), 5-I29.

75 F. Monsalve Serrano, O. De JuÁn Asenjo, Juan de Lugo y la libertad en economía: el análisis económico escolástico en transición, in: Procesos de mercado: revista europea de economía política (2006) 217-243.

76 Assertiones theologicae de contractu emptionis et venditionis, ad quas praeside Paulo Laymann publice respondebit VALENTINUS Schubin, Monachii I6I6; Assertiones ex theologia morali de vario discrimine iuris et facti, ad quas praeside Paulo Laymann publice respondebit JOHANNES HiCKEN, Monachii I6I9.
77 See P. Laymann, Theologia moralis in quinque libros partita, quibus materiae omnes practicae, cum ad externum ecclesiasticum, tum internum conscientiae forum spectantes nova methodo explicantur, lib. 3 (De iustitia et iure ceterisque virtutibus cardinalibus), Monachii I625.

78 P. Laymann, Jus canonicum commentario perpetuo explicatum, Dilingae 1698. 
design of the book as a commentary on the decretals, rather than as a systematic study obeying its own inner logic, by appealing to jurists' ordinary habits of discussing canon law by following that pre-established pattern. He thus wanted to render Laymann's explanations more reader-friendly.

Laymann's attention to canon law per se was indicative of a growing trend amongst Jesuit scholars in the seventeenth century to not only study law for the benefit of moral theology, but also for its own sake. By the mid-seventeenth century we witness the birth of vast, systematic and influential books on various branches of law. An exciting example of this turn towards a Jesuit legal science, notably with regard to contract law, is the Spanish Jesuit Pedro de Oñate's (I 568-I646) four-volume treatise On Contracts, published posthumously in 1646 (De contractibus). ${ }^{79}$ Pedro de Oñate, who had been a student of Suárez at Alcalá de Henares, became provincial of the Jesuit order in Paraguay in I6 I 5 . By the end of his term, he had co-founded the University of Córdoba (Argentina) and eleven colleges. In I 624 he was designated professor of moral theology at the Colegio San Pablo in Lima (Peru). His treatise On Contracts is one of the most extensive treatises on both general and particular contract law that has ever been written; in it Oñate discusses all contracts from the point of view of AristotelianThomistic philosophy. He borrows extensively from the Romano-canon legal tradition, Molina, Sánchez and Lessius, but has the merit of giving an ultimate synthesis of all the problems pertaining to contract law. It is a three-volume testament to a five hundred year-old tradition in scholastic contract doctrine which is unparalleled in its comprehensiveness.

The first volume of Pedro de Oñate's On Contracts is a systematic account of general contract doctrine (de contractibus in genere), the second deals with gratuitous contracts (de contractibus lucrativis), e. g. donations, agency, dowry, etc., while the third offers a meticulous analysis of all onerous contracts (de contractibus onerosis), e.g. sale-purchase, rents, bills of exchange, etc. At the outset of his treatise, Oñate warns his reader that contract law is both an extremely vast (vastissimum) and difficult (difficillimum) field of study. Distinguishing between more than thirty particular contracts, he admits that contract law is an immense ocean or, rather, an infinite chaos. Contract law is founded upon unstable ground, which prevented any scholar before him to treat it as

79 See E. Holthöfer, Die Literatur zum gemeinen und partikularen Recht in Italien, Frankreich, Spanien und Portugal, in: Handbuch der Quellen und Literatur der neueren europäischen Privatrechtsgeschichte, ed. by H. CoING, 2.I, München I977, 368 and 49I; I. Birocchi, Causa e categoria generale del contratto. Un problema dogmatico nella cultura privatistica dell'età moderna, I. Il cin- quecento, Torino 1997, 271-289; E. Fernández, s. v. Oñate, in: Diccionario histórico de la Compañía de Jesús biográfico-temático, ed. by C. O’Neill, J. DomínGUEZ vol. 3, Roma, Madrid 200I, 2870-287I. 
thoroughly. Moreover, contract law is very difficult. According to Oñate, this has to do with the avarice of man, which mostly expresses itself through the use of contracts, since contracts are the juridical means by which money and property are exchanged. On top of this, various legislators have tried to rule on the same matter in different ways and have issued a plethora of different laws.

It is worthwhile noting, however, that Pedro de Oñate also points out that understanding contract law is extremely useful (utilissimum). Contract law is essential not only to businessmen, lawyers, judges and public officials, but to theologians as well. A sound knowledge of contract law is absolutely necessary for theologians, certainly for those who are involved in the sacrament of confession (est materia haec theologis, iis maxime qui sacris aures confessionibus praebent, pernecessaria). ${ }^{80}$ The reason is simple: on the earthly pilgrimage towards God, it is impossible not to enter into contracts.

Not only was law increasingly studied for its own sake, in the second half of the seventeenth century Jesuit legal scholarship evolved into a real science of law. This is obvious from the French Jesuit Joseph Gibalin's (I 592-I67I) systematic and universal treatises on various legal topics. Gibalin was a professor of canon law and theology at the Jesuit college of Lyon and an occasional counsellor to Richelieu. On top of that he wrote voluminous treatises on private and commercial law. The mere title of his works are significant of what is called here the turn towards a Jesuit science of law : De universa rerum humanarum negotiatione tractatio scientifica (1663): a scientific treatment of the whole of human business, focussing on commerce and contracts. Its extended title in the Lyon-edition of I 663 is even more emblematic of the fusion of the entire legal and theological traditions into a single legal science: ${ }^{8 \mathbf{r}}$

A scientific treatise (tractatio scientifica) on universal human business, to be used in both courts, and derived from natural law, church law, civil law, Roman law, and French law. In this book, equity in human business is explained in a scientific and solid manner (scientifice et solide), namely in all its causes and subjects, in the universal and particular forms of contracts, exchanges and the various kinds of synallagmatic relationships, and in the obligations that are created by them; this book also shows what the right and false use of human sciences and arts are, the essence of the various ranks, offices, and duties. Hence it treats the whole of economics and politics.

80 Cf. P. de OÑATE, De contractibus tomi tres, Romae I646, tom. I, tract. I, pr., num. 3, p. I.

8I J. Gibalin, De universa rerum humanarum negotiatione tractatio scientifica, utrique foro perutilis. Ex iure naturali, ecclesiastico, civili, romano, et gallico. In qua negotiorum humanorum aequitas per omnes negotiationis causas, materias, formas universales ac singulares contractuum, commer- ciorum, atque sunallagmatoon diversa genera, ex iisque ortas obligationes, scientifice et solide explicatur, humanarum scientiarum et artium rectus ac pravus usus demonstratur, singulorum statuum, officiorum ac munerum rationes, atque adeo universa oeconomica et politica traduntur, Lugduni 1663. 
82 J. Gibalin, Scientia canonica et hieropolitica opus novum, in tres tomos partitum. In quo singula, quae toto corpore iuris Pontificii sparsa sunt, ad certa, et indubitata principia reducuntur; et ex illis innumerae quaestiones, ad forum tum internum, tum externum pertinentes, facile et solide, quamvis non semper ex vulgi sensu, explicantur. Privati Galliae mores, ac iura cum Romanis conciliantur: universa denique moralis Theologia, ex certis, et constantibus scholasticae principiis, Patrum sensu, et ecclesiasticis legibus docetur, Lugduni I670. It should be noted that C. Sommervogel, Bibliothèque de la Compagnie de Jésus, Bruxelles, Paris I 892, tom. 3, col. I4OI, num. 7 wrongfully made reference to the title of this work as being >Sententia canonica et hieropolitica, etc. $<$ a mistake copied by P. Duclos, s. v. Gibalin, in: Diccionario histórico de la Compañía de Jesús biográficotemático, vol. 2, Roma. Madrid 200I, I727, and by B. BASDEVANT-GAUDEMET, s. v. Gibalin, in: Dictionnaire historique des juristes français XIIe-XXe siècle, ed. by P. Arabeyre, J. L. Halpérin, J. Krynen, Paris 2007, 365 .

83 Cf. G. Jerouscheк, Für und Wider der Hexenverfolgung. Zu Heinrich Kramers Malleus Maleficarum und Friedrich Spees Cautio Criminalis, in: Europäische Religionsgeschichte. Ein mehrfacher Pluralismus, ed. by H.G. KIPPENBERG, J. RÜPKE, K. VON STUCKRAD, Göttingen 2009, 253-287; D. VANYSACKer, Un point de vue de juriste, de théologien ou plutôt de jésuite au service de la ContreRéforme? L'attitude de Martín Antonio Delrío (I 55 I-I608) et Joannes David (I546-I6I3) envers la sorcellerie et le mal parmi nous, in: The Quintessence of Lives. Intellectual Biographies in the Low Countries Presented to Jan Roegiers, ed. by D. VANYsACKer, P. Delsaerdt, J.-P. DelVille, H. Schwall, Turnhout et al. 2010, 63-82.

84 Biographical details on Ignaz Schwarz, who served as a history professor at the University of Ingolstadt, are provided by C. SoM-

The same turn towards a scientific and comprehensive treatment of legal affairs can be witnessed in Joseph Gibalin's systematic treatise on canon law, the title of which is equally indicative of the turn towards legal science: Scientia canonica et hieropolitica. ${ }^{82}$ Again, the full title of this scientific treatise, as can be found in the Lyon-edition of 1670 , is telling enough:

A new treatise on the science (scientia) of canon law and hieropolitics. It reduces all singular rules that are scattered over the body of pontifical law to certain and indubitable principles. On the basis of these principles, innumerable questions are solved, albeit not always in a necessarily conformist way, which concern both the internal and the external fore. In this book French private morals are reconciled with Roman morality. Last but not least, universal moral theology is taught on the basis of certain and constant academic principles, the teachings of the Fathers and the law of the Church.

There hardly seems to be any place better suited to conclude this brief "tour d'horizon " of some of the major Jesuit works on law in the early modern period than Joseph Gibalin's epitome of Jesuit legal science. Of course, further examples of Jesuit experts in legal affairs could be cited, for example, Martín Antonio Delrío's (I 55 I-I608), Joannes David's (I 546-I6I3) and Friedrich Spee's (I 59 I-I635) contributions to the early modern debate on criminal law, particularly on witchcraft and magic. ${ }^{83}$ Although the first half of the seventeenth century was undoubtedly the golden age of Jesuit moral and legal thinking, Jesuits around the world have continued to excel in legal studies right up until today. For example, in $\mathrm{I} 74 \mathrm{I}$, of worthy mention would be the Jesuit historian Ignaz Schwarz (I690-I763) from Münckhausen who published his Institutions of Universal Public Law (Institutiones iuris publici universalis) as a reply to the natural law treatises of Grotius, Pufendorf, Thomasius, Vitriarius and Heineccius. ${ }^{84}$ Jesuit legal scholarship has also kept on shining in international law, most notably in the international law debates and the law of war and peace. Jesuits like Yves de la Brière (I877-I94I) and Robert Regout (I896-I942) are worthy of investigation in this respect. ${ }^{8_{5}}$

MERvoGel, Bibliothèque de la Compagnie de Jésus, tom. 7, Bruxelles, Paris I 896, col. 946-949, and in H. Dickerhof, Land, Reich, Kirche im historischen Lehrbetrieb an der Universität Ingolstadt. Ignaz Schwarz I690I763, Berlin I967. I wish to thank Professor Wolfgang Forster for bringing the latter work to my attention.

85 On Regout, see H. DE Waele, Regout als jurist, in: Robert Re- gout: Maastricht I 896 - Dachau I942, ed. by M. J. F. LINDEIJER S. J., A. Welle, Drachten 2004, IO3-I23. It is no coincidence, of course, that a couple of years before De la Brière and Regout published their writings on the just war, J. M. BitTremieux had just re-edited Lessius's lectures on law and peace in: Lessius et le droit de guerre: contribution à l'histoire des doctrines théologiques sur la guerre, Bruxelles I920. 
4. Law and theology in confessional catholicism: Nachleben

Joseph Gibalin's attempt to encapsulate the entire human life into scientific legal structures is nothing less than the pinnacle of a century of Jesuit involvement in legal and moral theological studies. Starting with rather traditional manuals for confessors, the Jesuits gradually felt the need to invest themselves more deeply into the universe of law composed of natural law, the Romanocanon legal tradition and even contemporary positive law. This remarkable phenomenon has often been perceived as a threat to the authentic Christian spirit - a sentiment that the Jansenists and Blaise Pascal, in particular, would not cease repeating.

In the course of the 2 oth century, mainstream theology seems to have taken this warning increasingly serious. Influential theologians, such as Henri de Lubac (I896-I99I), have called for a return to the allegedly more authentic Christian spirit found in the writings of the Fathers of the Church. The Church's age-long involvement with Roman law and Aristotelian moral philosophy - the pillars of the scholastic - bore the brunt of Lubac's criticism. It is actually easy to forget that Lubac belonged to the same Jesuit order that had previously went to such great lengths to promote the synthesis of law and theology. ${ }^{86}$ Therefore, it may be useful to recall the truly spiritual roots of the early modern Jesuits' involvement in legal scholarship.

The Jesuits wanted to bring back as many people as possible to their Creator. As consultants to people of all walks of life, they tried to give concrete answers on how they needed to act in specific circumstances of life without losing the hope of gaining salvation at the Last Judgment. Put differently, the scientific legal scholarship of the Jesuits was a handmaiden of their pastoral activity and spiritual ministry: ad maiorem Dei gloriam. As was beautifully explained by Súarez, law was considered to be an indispensable tool for any confessor with an honest concern for solving the most diverse cases of conscience.

A sound knowledge of law was deemed necessary for the practical purpose of determining the subjective rights and duties of people of all walks of life in their day-to-day practices. Romanocanon law was the main instrument of precision for Jesuit moral theologians to guide the flock. However, the pronounced legal outlook of Jesuit moral thinking is not an exception in the rich field

86 Uniformity of doctrine has always

been a thorny issue within the

Jesuit order; cf. M. FrIEDRICH,

Theologische Einheit und soziale

Kohärenz. Debatten um die Ho-

mogenität von doctrina im Jesui-

tenorden um 1600 , in: Vera

Doctrina (n. 7) 297-324. 
87 As regards the influence of the moral theologians on R.J. Pothier's juridical doctrines themselves, see J. Gordley, Philosophical Origins (n. 64).

88 S. Pufendorf, De officio, Ad lectorem, in: S. Pufendorf, De officio, ed. G. Hartung, Berlin I997, p. 5: ’Manifestum igitur est, ex tribus velut fontibus homines cognitionem officii sui, et quid in hac vita sibi tanquam honestum sit agendum, tanquam turpe omittendum, haurire; ex lumine rationis, ex legibus civilibus, et ex peculiari revelatione divini numinis. (...) Inde et tres separatae disciplinae proveniunt, quarum prima est juris naturalis, omnibus gentibus communis: altera juris civilis singularum civitatum, quae tam multiplex est, aut esse potest, quot numero sunt civitates, in quas genus humanum discessit. Tertia theologia moralis habetur,

of early modern Catholic ethics. With Dominicans, Franciscans, Augustinians, Carthusians and other religious orders, the Jesuits shared the view that making Christian spirituality operational in day-to-day life required the tool of law. Still, the depth of legal analysis attained by Jesuits, such as Suárez, Sánchez, Molina, Lessius, Lugo, Laymann, Oñate and Gibalin, remains unparalleled.

The scholastic synthesis of law and morality left its imprint on the subsequent legal and moral theological tradition. Jurists such as Sigismondo Scaccia (ca. I 564-I634), Hugo Grotius (I $583-$ I645), Giovanni Battista de Luca (I613-1683), Viscount Stair (I6I9-I695) and Samuel Stryck (I640-I7I0) quote and debate the juridical analyses of the theologians. Alphonso de Liguorio (I696-I787), the patron saint of the moral theologians, drew heavily on Jesuit legal analysis. His Moral Theology (Theologia moralis) comprised a systematic exposition on the law of obligations. Even Robert Joseph Pothier (I699-I772), a contemporary of Liguorio, showed himself indebted to the moral theological tradition. The sole project of giving a systematic account of the law of obligations from the perspective of both the external court and the court of conscience reminds us of the scholastic undertakings. ${ }^{87}$

The Catholic fusion of theological and juridical thinking on the eve of modernity might strike some as a return to a pre-modern world, the end of which had just been heralded in by the Protestant reformations. It proves particularly interesting, for example, to compare the above-sketched symbiosis of legal and theological scholarship with the specialisation of disciplines as proposed by Samuel Pufendorf (I623-I699) in the marvellous introductory note to his work On Duties (De Officio). In Pufendorf's opinion, to each of the three sources of duties (I. reason; 2. civil laws; 3. divine revelation) corresponds a separate discipline ( $\mathrm{I}$. natural law; 2 . civil law; 3. moral theology). ${ }^{88}$ Yet this is not how Catholic scholars in the early modern period saw it. They shared a widespread opinion that an expert moral theologian must also peruse the light of reason and the complex body of civil laws. However essential divine revelation in the Gospels may be, it is not a satisfactory guideline to find the right path to God's paradise.

Wim Decock*

* Fellow Research Foundation Flanders, Division of Roman Law and Legal History, K. U. Leuven, Tiensestraat 4I - box 3453 , B-3000 Leuven. Versions of this paper have been presented at a number of institutions, including the Facultés Universitaires SaintLouis Bruxelles (Café des droits anciens, supported by Drs. E. Falzone and Drs. M. Moulart), K.U. Leuven (Conference on the Jesuits in the Low Countries organized by Prof. R. Faesen and B. Deprez), and the Max-Planck-Institut für europäische Rechtsgeschichte (Montagsseminar led by Prof. Th. Duve). I am grateful to the organizers of these events as well as the participants at all of these venues for their comments. 